\title{
Phoma destructiva causing blight of tomato plants: a new fungal threat for tomato plantations in Brazil?
}

\author{
Adans A. Colmán ${ }^{1} \cdot$ Janaina L. Alves $^{1} \cdot$ Meiriele da Silva $^{1} \cdot$ Robert W. Barreto $^{1}$
}

Received: 17 July 2017 / Accepted: 24 October 2017 / Published online: 20 November 2017

(C) Sociedade Brasileira de Fitopatologia 2017

\begin{abstract}
Solanum lycopersicum is among the most important crops in Brazil. This crop is affected by a large range of fungal diseases that are recognized as major limitations for tomato production. Recently, plants grown in a greenhouse in Viçosa, Minas Gerais, Brazil, were found to bear severe blight symptoms. A pycnidial coelomycete was repeatedly found in association with necrotic tissues. The fungus had its morphology recognized as equivalent to that of Phoma and related genera. A phylogenetic analysis based on nrDNA (ITS) and partial $\beta$-tubulin (TUB) sequences led to the conclusion that the fungus involved was Phoma destructiva. Pathogenicity tests showed that, after 5 days, blight symptoms developed on leaves, flowers and stems of plants belonging to thirteen different tomato varieties tested. This fungal species is mostly known for causing post-harvest tomato rot, which is only regarded as a secondary disease in Brazil. This is in disagreement with the observations made in this work. Here, the disease symptoms caused by the fungus were very severe, fully justifying the scientific name of the pathogen. Under favorable environmental conditions, aggressive strains of $P$. destructiva, such as the one isolated in this study, may become significant threats to tomato plantations in Brazil.
\end{abstract}

Keywords Solanum lycopersicum · Coelomycetes · Didymellaceae $\cdot$ Pycnidial fungi $\cdot$ Phylogeny $\cdot$ Solanaceae

Section Editor: Trazilbo J. Paula Jr.

Robert W. Barreto

rbarreto@ufv.br

1 Departamento de Fitopatologia, Universidade Federal de Viçosa, Minas Gerais, Viçosa, MG 36570-900, Brazil
Solanum lycopersicum (Solanaceae) is one of the most important and broadly grown vegetables in the world. Brazil is among the major producers of tomato worldwide (Vale et al. 2007). A large range of fungal and oomycete diseases affect tomato (Jones et al. 2014; Lopes and Ávila 2005), some of which are universally regarded as major threats to tomato production, such as early blight, caused by Alternaria spp., and late blight, caused by Phytophthora infestans. Others, such as Phoma rot, are considered as having less relevance. In Brazil, this disease is considered to be of secondary importance (Inouie-Nagata et al. 2016). Although better known for causing post-harvest disease of tomato fruits, Phoma (Didymellaceae) occasionally also affects stems and leaves in the field (Kimati et al. 2005; Robl et al. 2014).

In July of 2015 several plants grown in a greenhouse in the campus of the Universidade Federal de Viçosa (Viçosa, state of Minas Gerais, Brazil), were found to bear severe leaf blight symptoms (Figs. 1a, b). Lesions also appeared on stems, which were similar to those seen on leaves (Fig. 1c). All diseased plants died because of the disease. A coelomycete asexual morph was repeatedly found in association with the necrotic tissues.

Direct isolation of the fungus in pure culture was performed through aseptic transfer of spores from colonized tissue onto PDA medium with a sterile fine-pointed needle. A representative isolate was deposited in the culture collection of the Universidade Federal de Viçosa, (Accession number COAD 2069). A representative dried specimen of infected tomato tissue was deposited in the herbarium of the Universidade Federal de Vicosa (VIC 44080). Sections of selected fragments of infected leaves bearing fruiting bodies were mounted in lactoglycerol for observation under a light microscope (Olympus BX 51) fitted with an Olympus e-volt 330 digital camera. Biometric data were recorded based on at least 30 measurements of various structures. 
Fig. 1 Phoma destructiva. a.

Early stages of infection of

Phoma destructiva on a tomato leaf. b. Ibid on flowers. c.

Necrotic spots on stem and on a young sprout. d. Tomato plant with severe blight 20 days after inoculation. e. Transversal section of a pycnidium showing a layer of conidiogenous cells. $\mathbf{f}$ Conidia with and without septa. Bars: $\mathrm{e}=8 \mu \mathrm{m}$ and $\mathrm{f}=20 \mu \mathrm{m}$
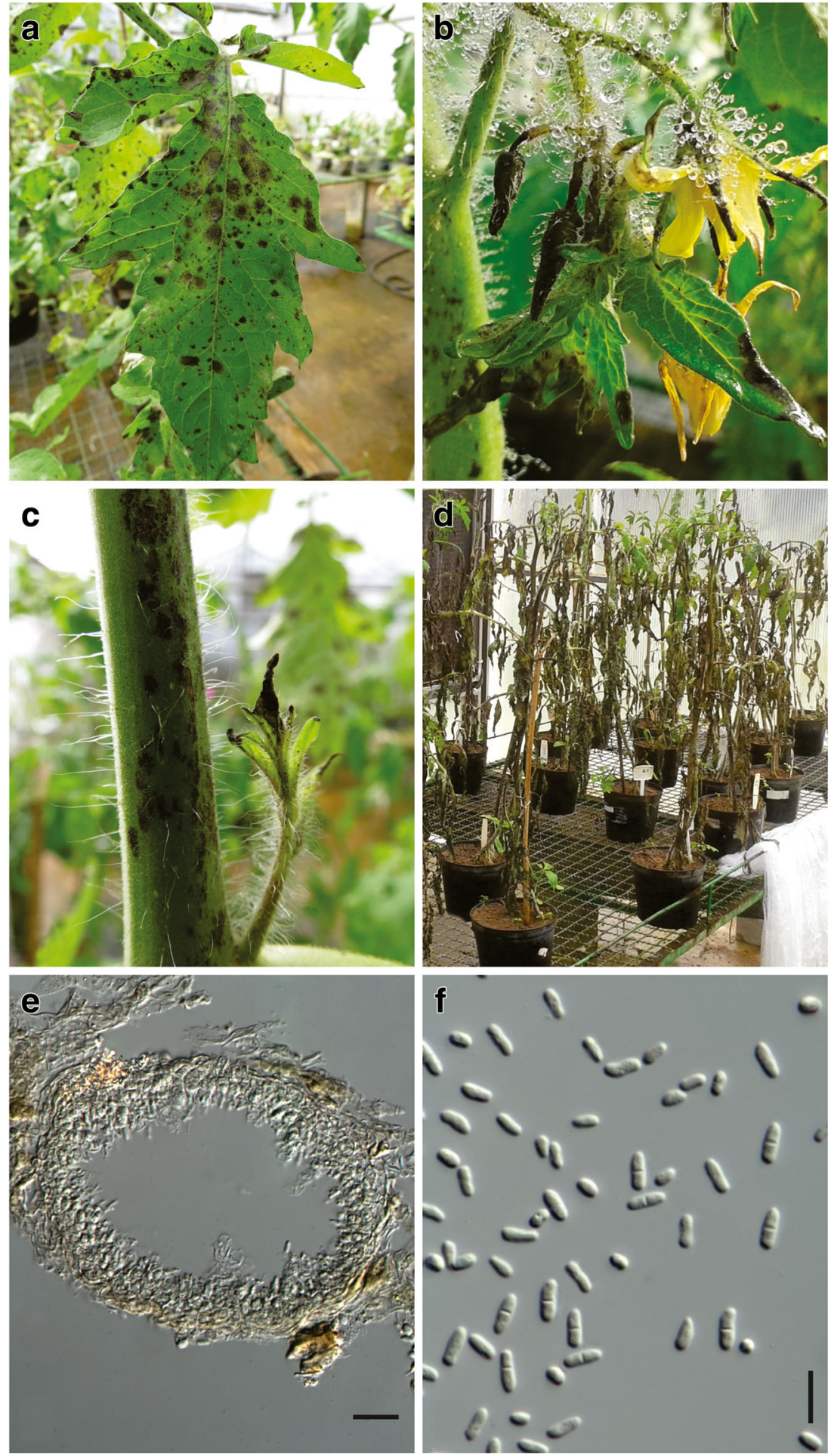

In order to obtain representative fungal DNA, COAD 2069 was grown on PDA at $25^{\circ} \mathrm{C}$ under a 12-h daily light regime for one week. DNA was extracted from approximately $40 \mathrm{mg}$ of fungal mycelium using the Wizard Genomic DNA
Purification Kit (Promega) following the protocol described by Pinho et al. (2012).

The nrDNA (ITS) and partial $\beta$-tubulin (TUB) sequences of COAD 2069 were amplified using the primer 
pairs ITS1/ITS4 (White et al. 1990) and T1/Bt2b, (Glass and Donaldson 1995; O’Donnell and Cigelnik 1997), following the protocols described by Pinho et al. (2012) and Sung et al. (2007). Amplification of ITS and $\beta$-tubulin, produced sequences of approximately 540 and $567 \mathrm{bp}$, respectively. The nucleotide sequences were edited with the DNA Dragon software (Hepperle 2011) and deposited in GenBank under accession numbers MF 426960 for ITS and MF448543 for $\beta$-tubulin. Additional ITS and $\beta$ tubulin sequences used in this study were retrieved from GenBank (Table 1).

ITS and TUB consensus sequences were compared with others deposited in the GenBank database using the MegaBLAST program. The most similar sequences were aligned using MUSCLE (Edgar 2004) and built in MEGA v.5 (Tamura et al. 2011). All of the ambiguously aligned regions within the dataset were excluded from the analyses. Gaps (insertions/deletions) were treated as missing data. Bayesian inference (BI) analyses employing a Markov Chain Monte Carlo method were performed with all sequences, first with each gene separately and then with the concatenated sequences (ITS and $\beta$-tubulin).

Before launching the BI, the best nucleotide substitution models were determined for each gene with MrMODELTEST 2.3 (Posada and Buckley 2004). Once the likelihood scores were calculated, the models were selected according to the Akaike Information Criterion (AIC). The SYM + I + G model of evolution was used for ITS, whereas GTR $+I+G$ was used for $\beta$-tubulin. The phylogenetic analysis of the concatenated sequences was performed on the CIPRES web portal (Miller et al. 2010) using MrBayes v.3.1.1 (Ronquist and Heulsenbeck 2003). The other phylogenetic analyses were conducted as described by Pinho et al. (2012). Sequences derived from this study were deposited in GenBank (http://www.ncbi. nlm.nih.gov/genbank) (Table 1), and the alignments and trees in TreeBASE (www.treebase.org) under entry number S21657.

A pathogenicity test was conducted including thirteen tomato varieties, namely: Forty, Ikram, Paronset, Platinum, Fusion, Santa Clara Siluet, Aguamiel, Caribe, Serato, Predador, Gladiador, Dominador and Vento. All varieties carry the $M i$ allele that confers resistance to root knot nematode (Meloidogyne spp.). COAD 2069 was grown on PDA medium at $25{ }^{\circ} \mathrm{C}$ for 7 days under a 12-h daily light regime and a conidial suspension $\left(1 \times 10^{6}\right.$ conidia $\left./ \mathrm{mL}\right)$ was prepared for inoculation. Plants were sprayed with this suspension until runoff and kept for 2 days in a dew chamber at $25 \pm 3{ }^{\circ} \mathrm{C}$ and later transferred to a greenhouse. In addition, two plants were sprayed with sterile water and kept under the same conditions to serve as controls.
Table 1 GenBank accession numbers of Phoma spp. DNA sequences used in the phylogenetic analysis

\begin{tabular}{|c|c|c|c|}
\hline \multirow[t]{2}{*}{ Fungal species } & \multirow[t]{2}{*}{ Strain number } & \multicolumn{2}{|c|}{ GenBank Acc. No. } \\
\hline & & ITS & TUB \\
\hline \multirow[t]{2}{*}{ Stagonosporopsis actaeae } & CBS 106.96 & GU237733 & GU237670 \\
\hline & CBS 105.97 & GU237734 & GU237671 \\
\hline P. acetosellae & CBS 179.97 & GU237793 & GU237575 \\
\hline \multirow[t]{2}{*}{ P. aliena } & CBS 379.93 & GU237851 & GU237578 \\
\hline & CBS877.97 & GU237910 & GU237579 \\
\hline \multirow[t]{2}{*}{ P. digitalis } & CBS 109.179 & GU237744 & GU237604 \\
\hline & CBS 229.79 & GU237802 & GU237605 \\
\hline \multirow[t]{2}{*}{ P. destructiva var. destructiva } & CBS 133.93 & GU237779 & GU237602 \\
\hline & CBS 378.73 & GU237849 & GU237601 \\
\hline P. destructiva & $\mathrm{TS} 24$ & KR559677 & KU507405 \\
\hline P. destructiva & ICMP 14884 & KT309887 & KT309473 \\
\hline $\begin{array}{l}\text { P. destructiva var. } \\
\text { diversispora }\end{array}$ & CBS 162.78 & GU237788 & GU237600 \\
\hline \multirow[t]{2}{*}{ P. bulgarica } & CBS 357.84 & GU237837 & GU237589 \\
\hline & CBS 124.51 & GU237768 & GU237590 \\
\hline P. crystallifera & CBS 193.82 & GU237797 & GU237598 \\
\hline \multirow[t]{2}{*}{ P. eupyrena } & CBS 374.91 & FJ426999 & FJ427110 \\
\hline & CBS 527.66 & FJ427000 & FJ427111 \\
\hline \multirow[t]{2}{*}{ P. herbarum } & CBS 615.75 & GU237874 & GU237613 \\
\hline & CBS 502.91 & FJ427022 & FJ427133 \\
\hline P. matteuciicola & CBS 259.92 & GU237812 & GU237627 \\
\hline \multirow[t]{2}{*}{ P. omnivirens } & CBS 991.95 & FJ427043 & FJ427153 \\
\hline & CBS 654.77 & FJ427044 & FJ427154 \\
\hline P. polemonii & CBS 109.18 & GU237746 & GU237648 \\
\hline \multirow[t]{2}{*}{ P. saxea } & CBS 419.92 & GU237860 & GU237655 \\
\hline & CBS 298.89 & GU237824 & GU237654 \\
\hline P. insulana & CBS 252.92 & GU237810 & GU237618 \\
\hline \multirow[t]{3}{*}{ P. multirostrata } & CBS 110.79 & FJ427030 & FJ427140 \\
\hline & CBS 274.60 & FJ427031 & FJ427141 \\
\hline & CBS 368.65 & FJ427033 & FJ427143 \\
\hline P. pereupyrena & CBS 267.92 & GU237814 & GU237643 \\
\hline P. commelinicicola & CBS 100.40 & GU237712 & GU237593 \\
\hline \multirow[t]{2}{*}{ P. costarricensis } & CBS 506.91 & GU237876 & GU237596 \\
\hline & CBS 497.91 & GU237870 & GU237597 \\
\hline
\end{tabular}

Phoma destructiva var. destructiva Plowr., Gard. Chron. II 16: 621. 1881.

Disease: On leaves, stems and flowers, starting as small black dots ( 1 to $2 \mathrm{~mm}$ diameter) that became circular to somewhat irregular, slightly depressing the plant tissues and forming zonate necrotic areas, where numerous fruiting bodies were formed. Lesions coalesced with age and led to entire blight of leaves, flowers and stems. 
Morphology: Internal mycelium indistinct; external mycelium absent; pycnidia immersed globose to irregular, 60$150 \times 70-180 \mu \mathrm{m}$, walls of thick textura angularis, ostiolate, brown, smooth; conidiogenous cells enteroblastic, ampulliform to doliiform, 4-6 $\times 3.5-8$, hyaline, smooth; conidia oval to ellipsoidal, $4.5-8 \times 2.5-3 \mu \mathrm{m}$, mainly aseptate but larger 1 -septate consistently produced, biguttulate, hyaline, smooth.

In culture: On PDA and PCA, fast-growing $(5.5-7.5 \mathrm{~cm}$ diameter after 7 days), edge entire, slightly convex, aerial mycelium cottony centrally, followed by an area of sparse mycelia, centrally pale olivaceous green alternating with dark mouse grey, periphery composed of immersed mycelium, diurnal zonation present; slightly humid centrally, olivaceous black reverse; sporulation abundant on PCA.

Typical leaf blight symptoms developed on leaves, flowers and stems of all ten tomato varieties five days after inoculation. The fungus was isolated from diseased tissues of inoculated plants, producing typical $P$. destructiva colonies, confirming the pathogenicity of COAD 2069 to a range of tomato cultivars (Fig. 1). The morphological features of the fungus isolated from diseased tissue were typical of Phoma destructiva (Table 2) and this identification was strongly supported by phylogenetic analysis of concatenated ITS and TUB gene sequences (Fig. 2).

Seven species of Phoma have been reported causing diseases on tomato in Brazil (Chen et al. 2015; Farr and Rossman 2016), including Phoma destructiva, which has been recorded causing fruit rot only once (Batista and Alves 1981). Nevertheless, that record is incomplete and obscure not supported by any morphological description of the fungus nor deposit of voucher specimens in herbaria or culture collections.
Based on morphology, P. destructiva has been separated into two varieties $P$. destructiva var. destructiva and $P$. destructiva var. diversispora differing in conidial size and septation (De Gruyter et al. 2002). Phoma destructiva var. destructiva is aseptate and has been reported as a common tomato and sweet pepper pathogen, causing fruit rot and small black spots on leaves and fruits in the tropics. Phoma destructiva var. diversispora is morphologically distinct from var. destructiva by producing larger one-septate conidia - a feature found in members of the section Phyllostictioides. (Aveskamp et al. 2010), and is considered to be restricted to Europe (De Gruyter et al. 2002). The "type variety" of $P$. destructiva var. destructiva was assigned to section Phoma whereas the other Phoma reported on tomato were allocated to other sections: Phoma lycopersici to section Boeremia and Phoma radicina to section Paraphoma (Chen et al. 2015; Gruyter et al. 2012). The ambiguity of some section designations has been discussed by Aveskamp et al. (2010). Phoma destructiva is an example of such an ambiguity because its two varieties are accommodated in two different sections due to the presence or absence of septate conidia (Aveskamp et al. 2010). Based on morphology, COAD 2069 fits into $P$. destructiva var. diversispora, however, it did not group with such a variety in the phylogenetic analysis. These observations suggest that emphasis put on spore size and septation by taxonomists to decide on the placement of fungi of this group in the past may have been misleading.

Phoma blight has been an important, although sporadic problem in some countries such as the United States and India (Jones et al. 2014). Recently, Phoma was recorded causing blight on greenhouse-grown tomato in Malaysia (Rashid et al. 2016). Seed transmission of Phoma diseases

Table 2 Morphology of Phoma species recorded on Lycopersicum esculentum worldwide

\begin{tabular}{|c|c|c|c|c|c|}
\hline \multirow[t]{2}{*}{ Fungi } & \multicolumn{3}{|l|}{ Conidia } & \multirow[t]{2}{*}{ Section } & \multirow[t]{2}{*}{ Reference } \\
\hline & Septation & Size $(\mu \mathrm{m})$ & Shape & & \\
\hline COAD 2069 & 1-septate & $4.5-8 \times 2.5-3$ & Oval to ellipsoidal & Phyllostictoides? & This study \\
\hline Phoma destructiva var. destructiva & aseptate & $3.5-6 \times 2-2.5$ & Oblong to ellipsoidal & Phoma & Aveskamp et al. 2010 \\
\hline Phoma destructiva var. destructiva & 1-septate & $8.5-11.5 \times 2-3.5$ & $\begin{array}{l}\text { Subglobose to ellipsoidal } \\
\text { or allantoid }\end{array}$ & Phyllostictoides & Aveskamp et al. 2010 \\
\hline Phoma exigua var. exigua & $1-2$ septate & $7-10 \times 2.5-3.5$ & $\begin{array}{l}\text { Subglobose, ellipsoidal } \\
\text { to oblong or allantoid }\end{array}$ & Boeremia & Chen et al. 2015 \\
\hline Phoma labilis & not mentioned & $3.5-5.5 \times 1.5-2$ & Ellipsoidal & Allophoma & Chen et al. 2015 \\
\hline Phoma lycopersici & aseptate & $5-8.5 \times 2-3.5$ & $\begin{array}{l}\text { Subglobose to ellipsoidal } \\
\text { or allantoid }\end{array}$ & Boeremia & Chen et al. 2015 \\
\hline Phoma radicina & not mentioned & $4-6 \times 2-3$ & Ellipsoidal to subglobose & Paraphoma & de Gruyter et al. 2012 \\
\hline Phoma terrestris & not mentioned & $4-6 \times 2-2.5$ & Ellipsoidal & Setophoma & de Gruyter et al. 2012 \\
\hline Phoma tropica & not mentioned & $3-4 \times 1-2$ & Ellipsoidal & Allophoma & Chen et al. 2015 \\
\hline
\end{tabular}


Fig. 2 Phylogenetic study of Phoma destructiva. Tree inferred from Bayesian analysis based on concatenated ITS and TUB sequences. Species from Brazil are shown in bold face. Bayesian posterior probabilities are indicated at the nodes. The tree was rooted with Stagonosporopsis actaeae (isolate CBS 105.96 and CBS 106.96)

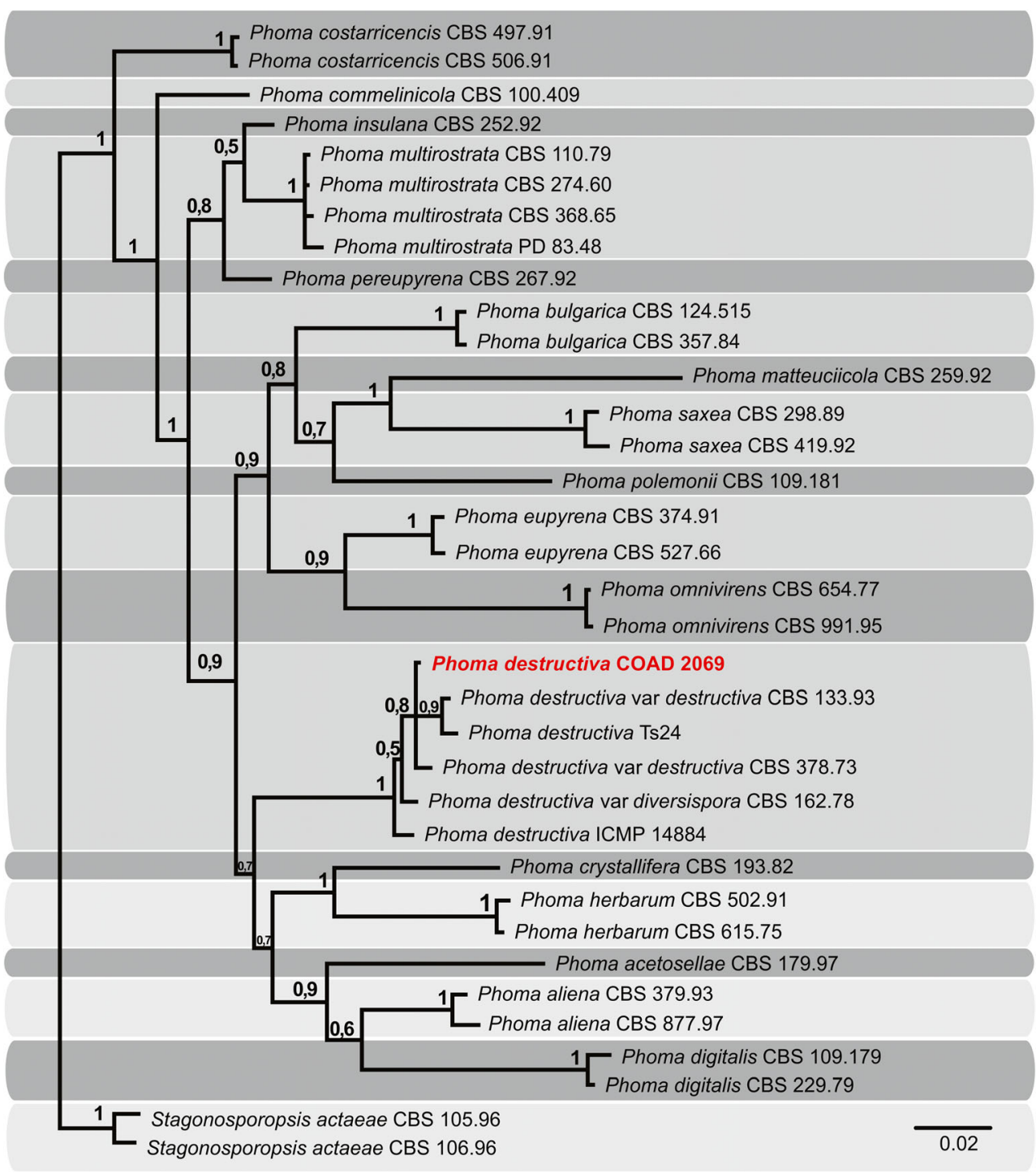

is known to be important in paprika and tomato. Colonized seed and transplant seedlings are thought to be involved in long distance dissemination of the pathogen (Jones et al. 2014). It is likely that, in the case of the outbreak observed in Viçosa, infected seeds have served as the source of inoculum. Therefore, considering the high level of disease severity observed on the various tomato varieties evaluated in this study, it is important to investigate what was the original source of $P$. destructiva and whether it can be disseminated by infected seeds. It is possible that the spread of the pathogen onto plantation areas, particularly under greenhouse conditions, may result in serious losses, posing yet an additional threat for this highly valuable crop in Brazil, for which disease management is already a constant challenge. Additionally, a more detailed comparison between isolates of $P$. destructiva associated with blight and those associated with post-harvest fruit disease should be conducted in order to clarify whether they represent distinct taxa.

Acknowledgements The authors wish to thank Fundação de Amparo à Pesquisa do Estado de Minas Gerais - FAPEMIG, Conselho Nacional de Desenvolvimento Científico e Tecnológico - CNPq and Coordenação de Aperfeiçoamento de Pessoal de Nível Superior - CAPES for financial support of the work.

\section{References}

Aveskamp MM, de Gruyter J, Woudenberg JHC, Verkley GJM, Crous PW (2010) Highlights of the Didymellaceae: a polyphasic approach to characterize Phoma and related pleosporalean genera. Studies in Mycology 65:1-60 
Batista MF, Alves MLB (1981) Doenças do tomateiro na região de Manaus. Fitopatologia Brasileira 6:573-574

Chen Q, Jiang JR, Zhang GZ, Cai L, Crous PW (2015) Resolving the Phoma enigma. Studies in Mycology 82:137-217

Edgar RC (2004) MUSCLE: multiple sequence alignment with high accuracy and high throughput. Nucleic Acids Research 32:1792-1797

Farr DF, Rossman AY (2016) Fungal databases, systematic mycology and microbiology laboratory, ARS, USDA. Available at: http://nt. ars-grin.gov/fungaldatabases/. Accessed 10 June 2016

Glass NL, Donaldson GC (1995) Development of primer sets designed for use with the PCR to amplify conserved genes from filamentous Ascomycetes. Applied and Environmental Microbiology 61:1323-1330

Gruyter J, Boerema GH, van der Aa HA (2002) Contributions towards a monograph of Phoma (Coelomycetes)-VI-2. Section Phyllostictoides: outline of its taxa. Persoonia 18:1-53

Gruyter J, Woudenberg JHC, Aveskamp MM, Verkley GJM, Groenewald JZ, Crous PW (2012) Redisposition of Phoma-like anamorphs in Pleosporales. Studies in Mycology 75:1-36

Hepperle D (2011) DNA Dragon 1.4.1 - DNA Sequence Contig Assembler Software. Available at: www.dna-dragon.com. Accessed 16 June 2016

Inouie-Nagata AK, Lopes CA, Reis A, Pereira RB, Quezado-Duval JB, Lima MF (2016) Doenças do Tomateiro. In: Amorim L, Rezende JAM, Bergamin Filho A, Camargo LEA (eds) Manual de Fitopatologia. Vol. 2. Doenças das Plantas Cultivadas. Ceres, São Paulo, pp 697-732

Jones JB, Zitter TA, Momol TM, Miller SA (2014) Compendium of tomato diseases and pests, 2nd edn. APS Press, St. Paul

Kimati H, Amorim L, Bergamin Filho A, Camargo LEA, Rezende JAM (2005) Manual de Fitopatologia: Doenças das Plantas Cultivadas, vol 2, 2nd edn. Editora Agronômica Ceres Ltda, São Paulo

Lopes CA, de Ávila AC (2005) Doenças do tomateiro. Embrapa Hortaliças, Brasília

Miller MA, Pfeiffer W, Schwartz T (2010) Creating the CIPRES Science Gateway for inference of large phylogenetic trees. In: Proceedings of the Gateway Computing Environments Workshop (GCE). New Orleans. pp. 1-8
O’Donnell K, Cigelnik E (1997) Two divergent intragenomic rDNA ITS2 types within a monophyletic lineage of the fungus Fusarium are non-orthologous. Molecular Phylogenetics and Evolution 7:103-116

Posada D, Buckley TR (2004) Model selection and model averaging in phylogenetics: advantages of Akaike information criterion and Bayesian approaches over likelihood ratio tests. Systematic Biology 53:793-808

Pinho DB, Firmino AL, Pereira OL, Ferreira Junior WG (2012) An efficient protocol for DNA extraction from Meliolales and the description of Meliola centellae sp. nov. Mycotaxon 122:333-345

Rashid TS, Sijam K, Nasehi A, Kadir J (2016) Occurence of Phoma blight caused by Phoma destructiva on tomato (Solanum lycopersicum) in Malaysia. Plant Disease 100:1241-1242

Robl D, Thimoteo SS, de Souza GCCF, Beux MR, Dalzoto PR, Pinheiro RL, Pimentel IC (2014) Occurrence of Candida orthopsilosis in Brazilian tomato fruits (Lycopersicum esculentum Mill.) Brazilian Journal of Microbiology 45:105-109

Ronquist F, Heulsenbeck JP (2003) MrBayes 3: Bayesian phylogenetic inference under mixed models. Bioinformatics 19:1572-1574

Sung GH, Sung JM, Hywel Jones NL, Spatafora JW (2007) A multi-gene phylogeny of Clavicipitaceae (Ascomycota, Fungi): identification of localized incongruence using a combinational bootstrap approach. Molecular Phylogenetics and Evolution 44:1204-1223

Tamura K, Peterson D, Peterson N, Stecher G, Nei M, Kumar S (2011) MEGA5: molecular evolutionary genetics analysis using maximum likelihood, evolutionary distance, and maximum parsimony methods. Molecular Biology and Evolution 28:2731-2739

Vale FXR, Jesus Junior WC, Rodrigues FA, Costa H, Souza CA (2007) Manejo de doenças fúngicas em tomateiro. In: da Silva JHL, Vale FXR. (Org.) Tomate: tecnologia de produção. Suprema, Visconde do Rio Branco, pp 159-197

White TJ, Bruns T, Lee S, Taylor J (1990) Amplification and direct sequencing of fungal ribosomal RNA genes for phylogenetics. In: Innis MA, Gelfand DH, Sninsky JJ, White TJ (eds) PCR protocols: a guide to methods and applications. Academic Press, San Diego, pp 315-322 